\title{
In His Own Words: Siegfried "Zig" Engelmann Talks about What's Wrong with Education and How to Fix It
}

\author{
William L. Heward ${ }^{1}$ • Jonathan W. Kimball ${ }^{2}$ Kelly A. Heckaman ${ }^{3} \cdot$ James D. Dunne $^{4}$
}

Published online: 1 September 2021

(C) Association for Behavior Analysis International 2021

Siegfried "Zig" Engelmann devoted his life to developing and refining Direct Instruction (DI), a powerful teaching system that combines logical analysis of the content students are to learn, thoughtful selection and sequencing of instructional examples, clear communication between teacher and student, high rates of active student responding, reinforcement and corrective feedback, practice to mastery, and judicious review.

Thousands of children and adults owe their literacy to teachers who skillfully presented DI programs developed by Engelmann and colleagues. To learn more about Engelmann's approach to instructional design and achievements as a pioneering scientist, see Barbash (2021) and Kame'enui (2021).

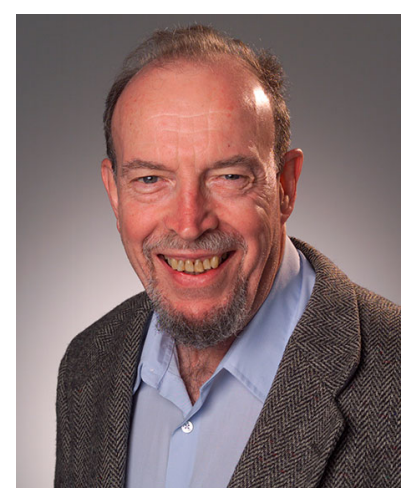

Siegfried “Zig” Engelmann (1931-2019)

"If the student hasn't learned, the teacher hasn't taught—-that's not a slogan, it's an operating principle."

William L. Heward

heward.1@osu.edu

1 Ohio State University, Columbus, OH, USA

2 Behavior Development Solutions, Bonita Springs, FL, USA

3 Valdosta State University, Valdosta, GA, USA

4 Wright State University, Dayton, OH, USA
In 1992, Engelmann served as guest faculty member for Ohio State University's Teleconference Seminar on Applied Behavior Analysis (Heward, 1989; Heward \& Dunne, 1993). The session was attended by doctoral students and faculty ${ }^{1}$ who prepared by reading photocopied galley proofs of Engelmann's soon-to-be-published book, War Against the Schools' Academic Child Abuse (Engelmann, 1992). In it he wrote:

The system panders and plays games because it is thoroughly incompetent at the top.... At present, there are strong advocacy groups for the spotted owl, the killer whale, the Alaska fur seal, and hundreds of other 'endangered species.' Paradoxically, millions of our kids are endangered. They will fail in school. They will suffer a very real form of child abuse. Yet these kids have far less real advocacy than the spotted owl does. (p. 8)

What follows is based on a transcript from an audio cassette recording the 90-min telephone discussion with Professor Engelmann on November 19, 1992. Never one to be shy or coy, he pulled no punches and called it as he saw it.

\section{Never Got Off the Target}

HEWARD: Hello Professor Engelmann. This is Bill Heward calling from sunny Columbus, Ohio. How are you today?

ENGELMANN: Okay. I'm in rainy Eugene, Oregon.

HEWARD: You've brought out quite a crowd. Fourteen Ph.D. students in special education and applied behavior analysis and three faculty colleagues are here with me. We've all been looking forward to today's seminar with you.

\footnotetext{
${ }^{1}$ Students: Dan Bullara, Marie Cull, Greg Drevno, James Dunne, Fred Haertel, Kelly Heckaman, Kim Killu, Jonathan Kimball, Rick Kubina, Stacy Martz, Mwajabu Possi, Phillip Ward, and Kimberly Weber. Faculty: John Cooper, John Eshleman, Bill Heward, and Diane Sainato.
} 
Let's get things started with a question I ask every guest faculty. Please tell us a little bit of your personal story. How did you become a behavioral educator?

ENGELMANN: I guess it was back when I was creative director in an advertising agency. Part of what we were doing for several clients was to develop ads and commercials for young kids. And the question came up, how much repetition is needed for kids to remember this stuff? Nobody knew the answer. I checked with the universities to see what they knew, and it turned out they didn't know anything! They had no info about trials or what was required.

So we started to do some little experiments to find out, and those experiments quickly turned into a school. I got more interested in teaching the kids than advertising, and I figured that's what I wanted to do. So, I made some films of some of the stuff I had done with kids, and then piddled around at various places and ended up at the Institute for Research on Exceptional Children at the University of Illinois, working first with [James] Gallagher and ultimately with Carl Bereiter. $^{2}$ And from there I just stayed with it. Never got off the target.

HEWARD: We're all glad you didn't. Your work has made a huge impact on how we train special education teachers at Ohio State. Before turning things over the students, I'd like to share a positive outcome of your work for my family. My wife Jill used Teach Your Child to Read in 100 Easy Lessons (Engelmann et al., 1983) to teach both of our kids how to read before they entered school (Dardig, 1987). With one it was more like 200 lessons, and not all of them easy! But in the end, the success you claimed was the outcome achieved.

At this point I'll turn things over to the students who are excited to talk with you.

\section{There's No Respect for Teaching}

OSU: You've written that funding agencies, educational publishers, administrators, and policy officials buy into developmental theories that espouse subjectivity and refuse to acknowledge the accomplishments of measurably superior instructional techniques. Given this resistance, what do you see as the future for effective instruction, and what can be done to change the infrastructure of the U.S. educational system?

ENGELMANN: That's a real good question. If we just start [with the idea that we should take responsibility for kids], everything that's required comes into focus: how we would monitor students' progress, how we would train the teachers, how we would measure our results. If we just take that one

\footnotetext{
2 https://www.youtube.com/watch?v=xitjOGjVWV4 This video was produced in 1965 by the Anti-Defamation League of the B'nai B'rith. It is a demonstration of the original Bereiter-Engelmann Preschool at Colonel Wolf School in Champaign, IL.
}

step of saying we're going to take responsibility for teaching these kids and we're going to have high, achievable standards, which means that all of our teachers are going to do it, and all our kids are going to do it.

It can be done. That's the terrible part about it, that's the frustrating part about it. In terms of how to get the machine to respond-by the machine I mean the education establishment - to be data based, to be sensible, to be sensitive to the kids' needs, to be empathic in terms of what you're doing to improve kids' performance, I don't know how you do, it but you have to keep trying.

You can get places doing things, but they're going to disappear as soon as there are new administrators with new ideas, because administrators have that latitude - their futures are not linked to the futures of the kids. Their successes are totally independent of the success of any teacher or any kid. They can be considered real hot-shot administrators and do nothing but introduce wall-to-wall failures, blind experimentation with kids that would not be permitted in any other field! Just total incompetence in terms of knowing what they're doing. And they can do that year, after year, after year. The whole system needs a real heavy boot in the pants. You're not going to change things through evolution. There are too many pieces out of place.

In California, where I ended up suing those guys [Engelmann v. State Board of Education, 1989] and the Court of Appeals upheld the decision, they just introduced a new law that gave them years before they had to comply with [the ruling]. So, we had a real specious victory at best. You ask, "Why would legislators vote for that?" Because it's financial, that's why. Education publishing is a big business. A lot of money changes hands. And the publishers are going to protect that. They're not going to change unless it's legislated.

In special ed, legislation came about through some heartfelt appeals and through a great deal of persistence. The same things need to be done for regular education, so there's a bill of rights and some form of consumer protection. As it is now, there's none, and the public doesn't know it. I'm trying to reach the public through this book, but there's not a great deal of interest in it. So, you just do what you can do.

You mentioned developmental theories. Developmental theories are totally insane [when it comes to education]. Consider a concrete situation, and ask yourself, "Okay I want to teach this kid something. Does developmental theory tell me anything I need to know?" You might get a vague hint about readiness. Readiness is one of those circular things that Skinner referred to where the definition is the cause. Like how do you know a kid's ready? When he does it. Ok, well, when will he do it? When he's ready. It just goes around and around.

If you ask for any details, like how much practice is needed? What should we present? How long is it going to take? None of those questions are answered by developmental theory. Nor is developmental theory sensitive to the variables you 
can use to teach. Developmental theory describes the organism in a global sense, but teachers don't deal with the organism in terms of the dimensions that you can describe developmentally. Teachers deal with those aspects of the environment that can be classified as stimuli and reinforcers, punishers and various $\mathrm{S}^{\mathrm{D}} \mathrm{S}$ and $\mathrm{S}$-deltas, and away we go. That's it. But developmental theory doesn't say word one about any of those things.

The fact that people use it is [because] there's no respect for teaching. Because all you need to do is take any concrete situation and sit down five, 5-year-old kids. There they are in front of you and you're going to teach them something. Now, are you going to operate on neurological or developmental information? Well, you could try, but what if it turns out that this kid on the end doesn't know something that's developmentally normal. For instance, the kid's supposed to know colors, but she doesn't know colors. So, what do you do at that point? You can go nowhere. Developmental theory does you no good.

Well, that was the short answer. [lots of laughter] I'll do them with more brevity after this.

\section{The Media and Educational Reform}

OSU: On Primetime Live tonight Diane Sawyer is presenting a story about what is happening in schools today. What role does and could the media play in promoting changes needed to improve schools?

ENGELMANN: If you want to put agencies on the sides of good guys and bad guys, the media is strictly on the side of the bad guys for a bunch of reasons. One, the media is only interested in conflict or controversy. Their idea of dealing with an issue is to make it an issue. They don't deal with prescriptive stuff, right and wrong, or they do it in a way that's controversial. Number two, the educational press doesn't know what learning is about or what causes it, so they rely on statements of school administrators and people promoting various plans for change. And almost without exception, these people are naïve. They've never done it themselves; they've never seen it done. But their wishful thinking gets picked up in the press as if it's the way to go.

Several recent examples are quite striking. One is the New American Schools Development Corporation [NASDC] (see Bodilly et al., 1996) and the projects they've funded that are going to develop this new wave of schools and all of that. ${ }^{3}$ If you go down the list of the schools they've funded, and the sum total experience of the various projects they feel have the

\footnotetext{
${ }^{3}$ The NASDC (n.d.) was a nonprofit founded in 1991 by CEOs from major corporations with the mission to "support the design and dissemination of "whole school reform' models."
}

pizazz to get the job done, only one has any experience. That's Slavin's. ${ }^{4}$ All the rest are just varying degrees of naivete. They're all going to fail. But when the press plays them up, they play up the human drama side because deep down inside these guys really think that if you just got in there and motivated yourself that you could teach those kids, or if you motivated the kids, they would learn.

They need to have their nose rubbed in it. Someone should take them around to like Chicago or like poorer areas in Ohio. Go into a school and start asking some fifth graders simple math questions or simple reading stuff and you would die! You have no idea how bad it is. They need to see that; they have no idea. What they're going to come up with is some superficial, global way of dealing with it like site-based management.

\section{Market-Based Reform}

OSU: Leading education reformers such as Chester Finn, John Chubb, and Terry Moe say that instruction and learning would improve significantly if schools came under the control of market pressures. Shanker [president of the American Federation of Teachers] counters by saying not all things work well in an open marketplace. What's your position with respect to this issue?

ENGELMANN: The notion that if we just open up schooling to the free market, the free market is going to do the job, misses what the problem is or what the solution is. The history of medicine is relevant here. Medicine didn't clean up its act until there were laws in place. The same thing will happen with education.

Without laws you're subject to open and senseless experimentation, which is what most educational reforms are. The educational reforms that you're probably going to hear about on that program tonight will promote practices that have never been demonstrated to be effective with kids, that have never been demonstrated to be uniformly teachable to teachers, or uniformly manageable by systems. Practices that have never been demonstrated to accelerate performance of kids are promoted as what we should do. In what other field is that kind of bullshit permissible?

The first thing we should do is rate instructional techniques and programs and give schools categorical information on whether each technique or program has been field tested and whether there's any substantive data to suggest it works. Then if a school wants to use a poorly rated program and gets poor

\footnotetext{
${ }^{4}$ Robert Slavin (1951-2021) was distinguished professor and director of the Center for Research and Reform in Education at Johns Hopkins University. Slavin developed the Success for All model of reform for elementary and middle schools in 1986.
} 
results, at least the public will know something about the degree to which the district is engaged in quackery.

OSU: Should teachers' income be dependent upon their students' performance? Should we take that a step further and not allow people to become administrators unless they have succeeded as teachers?

ENGELMANN: I think the first order of contingency should be on the administrators. It normally goes to the teachers, but they don't deserve this heat. [Teachers] do either what they're permitted to do or what they're required to do. It's the people who make the decisions about what the teachers do. If you place contingencies, real strict ones, on outcomes that are based on administrative decisions you'd clean up education tomorrow. Well, not tomorrow, but in 2 or 3 years it would be pretty well cleaned up. That's what it takes.

\section{Teach More in Less Time}

OSU: Would effective early childhood education make a difference in schools' performance?

ENGELMANN: Yes. Let's say our goal is to provide uniform excellence, to accelerate all kids' learning. You accelerate kids only in one way, and that's to teach them more in less time than would be anticipated. If you do things as they're traditionally done, the outcome is in the can. If, on the other hand, you use an intensive program that allows you to teach them more in the available time, you can accelerate them. You can correct the problem.

Let's make a super system. To do so, requires differential treatment among younger kids. We test all 3-year-olds and identify those kids who are in trouble, the ones who are seriously behind in language or whatever, for whatever reasons. We put them in school right away, and we make sure that they get caught up. We identify some others at 4 years old, and perhaps some more at 5 years old. So that when everyone else starts school at 6 years old, all these other guys are caught up. Now you won't have to worry about a wildly heterogeneous population. Because that's the population that's going kill us in terms of teaching effectively.

When we have a heterogeneous situation, one way or another the lower performing kids are going to get ripped off. And we may rip off some of the others too, but we will rip off the lower performers.

The only way we can help them is to provide a concerted effort directed at where they are. And the only way to do that is to group kids for instruction, not necessarily for other things during the day. So when we work with them, we can be efficient and present stuff that is appropriate for their level and give them appropriate corrections. When we do that, we can really move.
But the typical classroom is a whole different story. Say a third-grade teacher wants to do some magnificent project with the whole class. You got your three groups, your red birds, your blue birds, and your buzzards. The ones who are going to hold everything back are the buzzards. They're the kids who can't read, can't look stuff up, they're the ones who prevent the teacher from doing neat integrated curriculum activities that involve everybody. Without differential treatment at early ages, we're going nowhere. So, the general idea of starting disadvantaged or at-risk kids in school at a younger age is a good one. The actual mechanism for it to work requires a great deal of continuity from school to school and from neighborhood to neighborhood because the lower performing populations tend to move around more than higher-performing populations.

But it's doable. The only way to solve the problem of providing significant acceleration for all kids it is to reduce the variation in the population.

\section{Child Centered Learning}

OSU: I've been asked to advise the state on early childhood certification and outcome measures for early intervention. Forty-four members of the committee are developmentalists, and I'm the other one. [laughter] When I speak I feel like 44 rifles are pointed at me. The key words in these meetings are child choice and child-guided instruction. Any comments for me?

ENGELMANN: Developmentalists dislike teaching aimed at promoting specific skills because it's based on the notion that the kid is deficient in some way. They want to talk about the kids' strengths and that kids will learn somehow without teaching. There's obviously no data to suggest that whatsoever. If it's true that kids really aren't deficient and we do not have to teach them, then let's randomly go through a class and say, "Ok, let's give this kid an M.D. degree, and let's make this one a lawyer, right now. They're not deficient in an any way." When you look at it like that you say, that's obviously baloney. We're not going to do that.

Say we ask a kid to read a fourth-grade textbook, solve some math problems, and follow some instructions. Can we identify specific things he can and can't do? You better believe we can. Can we get fine-grained about what the kid can't do? Absolutely. We can tell what words he can't read, what things he can't calculate, which instructions he can't understand, which directions he can't follow. So now we've got a big list of things to accelerate this kid to the point where he can handle this textbook and function at the fourth-grade level.

How are we going to get there the fast way? Are they trying to say that this dinking around and this child-centered stuff is going to get them there? How are we going to account for the teaching of each of these things? 
Here are the minimum requirements for teaching. One: expose the kid to some examples of what it is we expect him to do. Two, give him direction that keys what he is to do. Three, provide enough practice so the kid masters it. If we just say that's what's required, the rest will follow.

\section{It's Just Being Sensible}

OSU: In your view, are logic and the rules of communication derived from induction or do they drive induction? The practical upshot is whether teacher education programs equip teachers to shape only those responses available from their students once those responses have been made, or whether they train teachers to focus more on antecedent conditions.

ENGELMANN: That's a really good question, and I don't know that I can answer it in a short period of time. The question cuts across a bunch of issues, one of which is the relationship between behavior theory and teaching. One of the problems you have with applying behavior theory to teaching is that behavioral theory itself is like an experimental design. It doesn't tell you how to derive rules or what the basis of the derivatives are, and some of the derivatives are logical. In other words, if it's logically impossible for a kid to figure out how to read without receiving a model providing the minimum amount of information that would be needed to read, the kid would not learn to read. Period. All done.

That provides a guide for determining the content of what we're going to teach. Let's say you pick some problem type in math. The first thing you would do is figure out all the problems that are solved the same way this one is going to be solved, regardless of how different they sound; if you go through the same steps to solve, it's the same problem even though it uses different words. The next thing you do is to figure what would be needed to sequence that stuff You make a whole bunch of quasi-logical decisions based on an analysis of the content. Once you get that done, now you're ready to play behaviorist. Because the bottom line is, whatever the kid does is the truth!

If you thought you were teaching $\mathrm{x}$ or that $\mathrm{x}$ was the $\mathrm{S}^{\mathrm{D}}$, and you find the kids are making consistent mistakes that suggest $\mathrm{x}$ prime is what they're responding to, then that's what they're responding to. Once you get that information, you're in good shape because now you can redo your teaching to precorrect it. But to reach that stage you have to start before the fact with a kind of logical analysis. Once you get to that stage, you're playing pure behaviorist. You don't worry about quasi-problems like where this kid should be. You put him where he is and move him up as quickly as possible. Sort of like [to your question], "Neither of the above, being analytic in a logical sense or being behavioral," it's just being sensible. When you do systems stuff, you just want to be sensible and avoid as many problems as you can and create as few as possible.

\section{At that Point You're a Behaviorist}

OSU: In the chapter on theories, you say "Doug Carnine and I had written a book titled Theory of Instruction (Engelmann \& Carnine, 1982) that is based on the idea that many major aspects of instructional design or curriculum development can be achieved analytically, without reference to kids or even behavior." You talked about this a little bit in your last answer. My question is, how do you differentiate Direct Instruction from behavioral approaches to instruction like Keller's PSI or precision teaching?

ENGELMANN: The big difference is probably that DI programs are designed with the idea that misteaching creates the problems kids have. If you're going to take credit for teaching kids, you need to take credit for misteaching them. Misteaching is created by poor curriculum, poor curricular sequences, and poor tasks. I'll give you an example.

The first version of the Sullivan Reading Program (Thompson, 1971) was supposed to be behavioral. But it really wasn't. I went up to Seattle where they had a large implementation of it. They brought in some of their top kids who were already in Unit J or something like that, way far down the line. I put some words the chalkboard and asked them to read the words. None of the kids could read one word. But they could perform at $100 \%$ in the Sullivan materials. Because they had learned to match these words and they knew something about the meaning of the words because they could do those meaning vocabulary type items. For whatever reason, however, they were seriously mistaught about what they should be doing. Because they had been reinforced for performing in the program. This is a case of applying behavioral principles to a program that wasn't very good.

What we try to do with Direct Instruction is to identify those aspects that are analytical. John Stuart Mill wrote a whole bunch of rules about induction (Mill 1843/2012), and those rules hold. Let's say I show you two things that are greatly different, like take a star and a big glob, and I say, "This a glerm and this is a glerm." Then I show you five more, all of which are greatly different from each other. I show you a rectangle, a trapezoid, they're all two-dimensional things, but they're greatly different shapes. In terms of variability, we would show that these things vary across a number of dimensions. The prediction would be that any new thing I present that falls within that range of variability you would identify as a glerm.

We can make all kinds of similar predictions. We can make predictions within the range, across the range, and they're all verified. This has great implications for how to teach something. It implies a great deal about what you would show as 
positive examples, and what you would show that kid as negative examples, things that are not a glerm. It wouldn't tell you a heck of a lot about things like how many trials you might present before you give him a break, the extent to which you would mass the trials, the type of reinforcer you'd use, and that kind of stuff, but it would tell you a lot about what he would have to learn and it would imply what are relatively efficient techniques for getting him going. A lot of the details of the curriculum — of what you're going to teach — are implied in that logical analysis.

This doesn't contradict a behavioral approach in any way; it just starts on a different level. If you're looking at it from a behavioral standpoint, you can't talk about an $\mathrm{S}^{\mathrm{D}}$ unless something is presented to the learner. But if you're designing something, nothing is presented to the learner, and you have to figure out what's going to be the $\mathrm{S}^{\mathrm{D}}$. It's just a different game. So how are you going to figure out what's going to be the $\mathrm{S}^{\mathrm{D}} \mathrm{s}$, what the examples will be, what the features will be? Will they be clean, will they be noisy, will you present them sequentially or as part of a big group? You've got to answer a whole bunch of questions like that. If you answer 'em right, you'll be efficient. If you answer them wrong, aarrggh!

But if you do answer them wrong, the kid's performance will let you know something's got to change. As soon as you start working with the kid, you're a behaviorist and whatever that kid does gives you incontrovertible information about what you ought to be doing. You have $S^{\mathrm{D}} \mathrm{s}$, you have responses from the kid, and you can figure out pretty well what the kid is operating from, you can see any mistakes. At that point you're a behaviorist.

\section{Kids Are Lawful}

OSU: You stated the videodisc program is criticized for not conforming to the scope and sequence of current curricula used in schools (Carnine et al., 1987). Could the videodisc program be adapted to fit curricula already in place to make it a little more palatable?

ENGELMANN: You have this paradox, if you do it the way they do it, you're going to fail as badly as they fail. We work with kids a lot. Kids are lawful. If they're seriously mistaught it's because somebody induced what they thought were $\mathrm{S}^{\mathrm{D}} \mathrm{S}$ when they were introducing something else that really confused the hell out of the kids. We see that a lot. For instance, we had 32 or 33 kids and we gave this little test to see how they handled simple fractions like $1 / 3$ and $1 / 2$ and while they could answer questions like whether a fraction was more than 1 whole or less than 1 whole, they had no idea what that whole was. They didn't know that that one whole was the same thing as when you count, 1,2,3. They had no idea that it was in reference to that. But if you go back and look at how this stuff is taught you see where the kids' confusion comes from. This illustrates some of the points about the last question. It shows what you should not do and why you should not do it. In a traditional sequence, kids are taught three examples: $1 / 3,1 / 2$, and $1 / 4$. The kids work ad nauseam with these examples, coloring little pictures, and so on.

Here's the rule about teaching with a stipulated range of examples: If you work repeatedly with a narrow range of examples, kids will not generalize outside that range. And the longer you work in it, the less likely they will generalize. It's an anti-generalization strategy. They work along with $1 / 3$, $1 / 2$ and $1 / 4$, and as soon as they move to anything else, the kids are absolutely bonked because what have they been reinforced for? They've been reinforced for ignoring the numerator, for finding one piece of the fraction and learning it's less than one whole. So try to convince kids that fractions can be more than one whole. No Virginia, a fraction doesn't mean all the parts are the same size, it means they're counted one time.

Why do kids have that misrule? Because from day one, they work with this little stupid geometric set of examples.

If you cut the videodisc program apart to make it interface with a school's current curriculum, all you do is get the same results they get. [By the second lesson of] the videodisc fraction program kids are dealing with fractions more than one whole and less than one whole. So obviously it wouldn't fit in with [the school's] sequence at all because they're not covering fractions that are more than one whole until the fifth grade. In terms of fractions that are less than one whole, the videodisc introduces a whole bunch of fractions real fast. And what they learn is the bottom number tells how many parts are in each group and the top number tells how many parts you color in.

Right away kids work with fractions that are more than a group and less than a group. You show them a fraction with four in the denominator and say,

"Ok, how many parts are in each group?" "Four."

"If the top number is less than four, what do you have?

Less than a group."

"If the top number is more than four, what do you have?

More than a group."

"Ok, get ready to tell me if each fraction is more than a whole or less than a whole."

And the top number starts changing, bang, bang, bang, bang! Real fast. And the kids are responding real fast. Now, you can give a kid a rule of how fractions work. No way you're going to integrate that with a school's current curriculum. Because the sequences that are used in schools have been shaped by tradition, they're largely the cause of the problems the kids have.

When kids fail with fractions, it's not like they understand all this stuff and then one day their head just freezes up on them. They didn't know fractions from day one. They've been so mistaught. But that's what I mean about analytical 
misrules. Fractions are what they are. And if the bottom number tells how many parts are in each group and the top number tells how many of those parts you use or have, then that's what you want to teach kids out of the hopper. And you want to teach it so kids can apply it to a broad range of examples, not some Mickey Mouse range that's going to create later problems because of stipulation.

\section{A Mad House of Uncontrolled Experimentation}

OSU: Dr. Cathy Watkins was our guest faculty member a few weeks ago. When she told us about Project Follow Through and how the results were ignored and covered up, I was outraged (Watkins, 1988). After reading your new book, I'm again outraged by the lack of concern for student success. In Chapter 1, "The Reform Cycle," you write that true reform will occur only when informed citizens become educationally literate and demand that schools, publishers, and colleges of education put their actions where their rhetoric is. Have you attempted to persuade any talk show hosts that your work would be worth presenting to the public at large?

ENGELMANN: I'm up for it all right! But, uh [he laughs] nobody's called. I think it's important to try to publicize. There is no investigative reporting in education. They write down what the educators say and report it as if it's the truth.

There are some concerned groups. Doug Carnine is working with professional groups like pediatricians, and they're shocked when they find out what's happened. They have no idea that new textbooks for teaching skills in the primary grades are never field tested with a single kid before they're published. They found that impossible to believe and they were shocked. And they said almost to the person that a lot of what they recommended to parents is based on the assumption that what schools do is shaped by reasonable data-based requirements. They had no idea it's just this mad house of uncontrolled experimentation treating kids as guinea pigs.

More efforts like [Carnine's] are needed. Howard Sloan at Western Michigan University has been doing things along the same line. He informs boards of education that their job is not to demure to the administration, for the simple reason that the administration does not know how to do the job, and that's pretty obvious from the success rate of the administration. These efforts are not big successes because they go against the grain. But if somebody comes out with a program claiming that kids who got to tear out every fifth page of the encyclopedia learned fast because it helps develop their Thanatos complex, releases id aggression, and a bunch of other great stuff, that would be played up a lot. [lots of laughter] No kidding, because that's commensurate with the level that they want to deal with this stuff. But until they begin looking at the concrete details of instruction, schools and the boards of education will do nothing but make stupid decisions.

Teaching is a highly technical business, and the solutions are highly technical, not global. You're working with this kid and when you're screwing up, you're screwing up for reasons that can be identified and corrected pretty easily. If somebody who knows what they're doing looks at what you're doing and gives you appropriate feedback. It's not magic, it's not covert, it's not intuitive, it just is.

\section{Let's Get Organized}

OSU: Driving to campus to today I saw a bumper sticker that read, "If the people lead, the leaders will follow." Would you comment on how that might be relevant to improving schools today?

ENGELMANN: The public has to be mobilized. Political figures are just that. The problem here is that the public doesn't know what the truth is. They know their kid doesn't know stuff. They can tell when their kid's failing, but they don't know how to deal with the schools, they don't know what's possible, they don't know what sensible alternatives are.

Let's put it like this. Back when we did Project Follow Through (Engelmann et al., 1988), they had all these different models. A lot of them were pretty fluffy, like the British infant school, the Cognitively Oriented Curriculum by Weikart (1971), and so forth. Each of these models had a parent program and the parent programs rated the school program, and there was absolutely no correlation between the effectiveness of the school and ratings by the parent program.

OSU: Many Americans complain about the status of education, but little is being done in an organized way to change it. What needs to be done to focus the American people on this issue to implement the needed changes?

ENGELMANN: I think there needs to be strong advocacy groups that identify academic child abuse and serious discrepancies between what's possible in the schools and what's currently being achieved. They should target schools and administrators who fail to do this and blow the whistle on them. Let the public know what's happening and let the public know about viable, reasonable alternatives. That's what has to be done.

It's very frustrating. You want discrimination?! Consider what's happening to your kid when he's 3 years below grade level and he's in this heterogenous classroom in California where they're studying literature and manifest destiny. And this kid can't even read! He's being discriminated against. He's being asked to learn the same stuff higher performing kids at grade level are required to learn, and he's expected to learn it in the same period of time because he's in this heterogenous class. C'mon, guys - get with the program! Who can 
you get on your bandwagon to help out? The Urban League, the Children's Defense Fund, the NAACP, the business roundtable? None of the above, not one.

So, you're out there like Don Quixote swinging away at the old windmill, doing what you can do. Just trying to organize meetings [to inform the public as to] how they can shape the administration, what questions they ought to be asking - not even recommending specific approaches, just recommending sensible techniques like: Don't install programs unless you have some basis for knowing they're going to work. Don't install them without having a bottom line about when you're going to pull the plug on them. Don't install them unless you know the teachers can uniformly teach them. But they can't even get to first base, can't even get meetings. It's really frustrating. I wish I did know what the answer was.

\section{The Behaviorists are the Good Guys}

OSU: The decline you describe in regular education seems to be going on in special education as well. In [the center where I was working] I saw a disturbing increase in things like gentle teaching being advocated, bad behavior management, putting kids into activities because that's what the curriculum called for and not because of what their needs were. Do we behavior analysts change our name and terminology and sort of hide? Should we just plug away with our effective techniques and hope that someone notices and wait for the public to come to us?

ENGELMANN: The bottom line, I think, is that if it requires a lot of work and if the work is criterion referenced so you can tell right away whether someone is doing it the right way or not, it's going to be resisted by the system. The educational system prefers the stuff that is blind procedural that anybody could do because it doesn't require technical skill. So, if community-based instruction just means we take kids out and mother hen them about while they're at K-Mart and MacDonald's, then that's what they do. They don't worry about how to teach the kids how to make change and other stuff that would make them independent. And if they can get away with it, that's what they'll do. They favor whatever techniques require the least amount of technical skill, unfortunately.

Sometimes I think changing the name in some respects might not be a bad idea, ... but I think it's unfortunate that we live in a culture that is so anti-intellectual that they don't even recognize the good guys. The behaviorists are fundamentally the good guys. Those are the guys who are saying, "I don't give damn about how bad things have been for you, I'm not going to try and change the past, ... your home life, .. . I'll accept you where you are, buddy. I'll [teach you] so you can be reinforced for doing a whole bunch of things that you can't do now." That's neat, that's wonderful. To have those guys trashed is just an insult to higher learning.

\section{The Man was Crying}

OSU: National Public Radio did a story recently about a new report by Gerald Bracey on the state of American education (Bracey, 1992). Bracey contends that since there's no shortage of scientists and mathematicians in the United States, we can't say our schools are failing. He also adds that SAT and other test score data are misleading, that some test scores are actually rising, and that international comparisons of students are wrong and misleading. Would you comment on Bracey's claim that everything is hunky dory and rosy with the American education system?

ENGELMANN: We're working with this interfaith organizing council in Chicago along with the Chicago White Sox and we're working with some of their lower performing schools. We're out in the schools and when we started testing these fifth- and sixth-grade kids, this one guy on the interfaith council had to leave the classroom because he was crying. The man was standing there just crying. He could not believe that those kids could not read a word or that they didn't know the answer to stupid first-grade questions. Not one kid, not two kids, but the whole damned classroom of kids!

I'd love to grab [that writer] by the shirt and take him into the schools and have him eat all his words. Because let me tell you, it's a hell of a lot worse out there than any of the data would ever suggest.

\section{Plant Trees}

HEWARD: Thank you so much Zig. This has been an incredible session and the room's abuzz. Before we say goodbye, is there something we didn't ask that we should have?

ENGELANN: [Without missing a beat] Yeah! [pause] And the answer is: No, I'm not totally nuts! I plant trees and stuff like that to maintain what sanity I have left.

\section{References}

Barbash, S. (2021). Science in the service of humanity: The astonishing contributions of Siegfried Engelmann. Perspectives on Behavior Science. https://doi.org/10.1007/s40614-021-00293-z

Bodilly, S. J., Purnell, S. W., Ramsey, K., \& Keith, S. J. (1996). Lessons from New American Schools Development Corporation's Demonstration Phase. RAND Corporation. https://www.rand.org/ pubs/monograph_reports/MR729.html. Also available in print form. 
Bracey, G. W. (1992). The second Bracey report on the condition of public education. The Phi Delta Kappan, 74(2), 104-108, 110-117.

Carnine, D., Engelmann, S., Hofmesiter, A., \& Kelly, B. (1987). Videodisc instruction in fractions. Focus on Learning Problems in Mathematics, 9(1), 31-52.

Dardig, J. C. (1987). Teaching your preschooler to read. The Gifted Child Today, 10(6), 46. https://doi.org/10.1177/107621758701000619

Engelmann, S. (1992). War against the schools' academic child abuse. National Institute for Direct Instruction. (Original work published 1992)

Engelmann, S., \& Carnine, D. W. (1982). Theory of instruction: Principles and applications (Rev. ed.). ADI Press.

Engelmann, S., Becker, W. C., Carnine, D., \& Gersten, R. (1988). The Direct Instruction Follow Through model: Design and outcomes. Education \& Treatment of Children, 11, 303-317.

Engelmann, S., Haddox, P., \& Bruner, E. (1983). Teach your child to read in 100 easy lessons. Simon and Schuster

Engelmann v. State Board of Education, No. 361906. (Sacramento Co. Superior Court of California, November 14, 1989).

Heward, W. L. (1989). A teleconference seminar in applied behavior analysis. Journal of Applied Behavior Analysis, 22, 454-455.

Heward, W. L., \& Dunne, J. D. (1993). A teleconference with Professor Fred S. Keller. The Behavior Analyst, 16, 341-345.
Kame'enui, E. J. Ode to Zig (and the Bard): In Support of an Incomplete Logical-Empirical Model of Direct Instruction. Perspect Behav Sci (2021). https://doi.org/10.1007/s40614-021-00302-1

Mill, J. S. (2012). A system of logic, ratiocinative, and inductive: Being a connected view of the principles of evidence, and the methods of scientific investigation. Cambridge University Press (Original work published 1843).

Thompson, L. J. (1971). The Sullivan Reading Program: Developed by Sullivan Associates, Menlo Park, California. Product development report No. 5. American Institutes for Research. Retrieved August 5, 2021 at https://files.eric.ed.gov/fulltext/ED058020.pdf

Watkins, C. L. (1988). Project Follow Through: A story of the identification and neglect of effective instruction. Youth Policy, 10(7), 711.

Weikart, D. P. (1971). The Cognitively Oriented Curriculum: A framework for preschool teachers. National Association for the Education of Young Children.

Publisher's Note Springer Nature remains neutral with regard to jurisdictional claims in published maps and institutional affiliations. 